\title{
Attitudes of university youth towards the issue of delinquent juvenile children through new media methods: ( a field study on Minia university students )
}

(1)

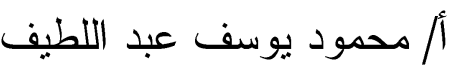

An introduction :

Internet is considered the first influential media methods on youth, this indicates the intensity of youth use and exposure for the internet considerably, because it is easier to use and more rapidly spreading. The vulnerability relies on what is what is proved and published through media methods from one youth to another. There is a class of youth realizes the nature of media dangers " positive and negative " and they are few and we find a class forming the majority of youth who have no background of media dangers and it's effect

The largest slice that is affected with new media methods is youth slice, because this age slice is affected quickly in terms of direction, picture and the effective picture culture that increases the impact of media methods on youth meaning the increase of obtaining knowledge and knowing society issues that threaten it's security and safety .

Forming or changing attitude is considered one of the most important aspects that affect new information methods , particularly forming youth attitude. It provides youth with information and issues, influences youth cognitive

$$
\text { 1 } 1{ }^{1}
$$


formation through exposure process, particularly in times of conflicts, wars and crises. Since new media methods are considered one of the influential methods in forming awareness and attitudes of all society classes in general and youth ones in particular towards the important issues of the society including childhood issues. Perhaps the most important factors that led us to concern with studying children issues are the emergence of social problems, violence and freedom issues and the increase of delinquent children, so , it must study the ability of new media methods on performing social roles to direct and change university youth attitudes towards this type of issues .

The phenomenon of juvenile delinquency and deviation is considered one the most prominent problems that Egyptian society and world societies suffer by which it create of psychological and social effects on children and what the leave of negative and dangerous effects on society. They influence economical and social power of the society .

The importance of new media methods is not restricted in covering issues of juvenile delinquency, providing youth with information about the raised researches, but it's role extends to treat this issue by guiding youth to solve it with excellent profession that contributes with an effective part in drawing the attention to the dangerous and renewable nature of these events that touch citizens security and society stability that requires from new media methods to exert further methodological and intellectual efforts that are able to direct the involved practices to be able to persuade the danger of delinquent juvenile children problem and it's future implications and what university youth must do to deal with this case . 
So, the researcher saw the necessity of studying this phenomenon to know the role of new media in forming knowledge and attitudes of university youth towards the phenomenon of delinquent juveniles, particularly on new media sites ( Face book ).

\section{Previous studies :}

The first axis - studies of new information methods :

The study of Magdy Mohammed Abdel Gawad Aldagher ( 2016) ( ) entitled " the role of new media in forming cognitions and attitudes of university youth towards the phenomenon of terrorism on the internet ". The study aimed at recognizing the role of new media methods and instruments in forming knowledge and attitudes of Saudi university youth towards the phenomenon of terrorism on the internet by applying on three universities in the kingdom . The study was applied on a purposive sample of ( 420 ) items . It is from the descriptive study and in terms of measurement to the quantitative researches . It relies on the survey method . The study was applied on youth at Saudi universities. The study found important findings including :

1-It was demonstrated that there is a clear excellence of new media methods in forcing youth to rely on it in forming their opinions and attitudes towards different issues including terrorism issues as a result of the availability of two basic factors that are : allowing these methods a freedom far greater than the conventional methods and the ability of these methods to achieve the audience participation effectively and actively .

2-The findings indicated Saudi universities students reliance on social networks sites in obtaining general information 
Attitudes of university youth towards the issue of delinquent juvenile children through new media methods: ( a field study on Minia university students(

with a percent of ( $41.67 \%)$. Then internet sites in general with a percent of ( $35.95 \%$ ) opposed threatening and fallback of the conventional methods. A relationship between the age and attitude isn't demonstrated relying on modern communication methods. While it was found in the variable of the scientific major, using social networks sites as a basic resource for information and sex conformity between male and female and their reliance on social networks sites .

3-The findings indicated the primacy of social networks sites ( face book - Twitter -You Tube - MySpace ), then list of the internet sites favor for Saudi universities students with a percent of ( $42.02 \%)$, then forums and satellites channels on the internet, then electronic press journals .

The study of Ekram Ahmed Fouad Elahwany (2015 ) ( ) entitled " problems of new media and it's coping methods on a sample of adolescents ". The present study aims at recognizing the adolescence stage and it's properties, defining new media and it's negative effects on adolescents and methods of coping and immunization, showing the most important problems of adolescents because of exposing to new media, knowing the most important technological innovations and developments and educating it's positivity and negativity ( the internet ). This study is classified as a descriptive one and relied on the method of sampling survey . It used the questionnaire instruments on ( 175 ) items of adolescents in prep - secondary stage. The study found important findings including :

1-Students percent who use internet to obtain information or entertainment, spending leisure time or communicating with relatives and friends is the highest percent (from $95: 96 \%$ ) 
Attitudes of university youth towards the issue of delinquent juvenile children through new media methods: ( a field study on Minia university students(

$2-94.8 \%$ of the students don't know what is the new media .

3- The percent of those who have special sites on the internet increases for male ( $38.8 \%$ ) than female ( $8.8 \%$ ) and vice versa concerning Electronic address .

The study of Hassan Abdel Rahman Taher (2015 ) ( ) entitled " youth ad media ". This study aims at recognizing the concept of new media, recognizing some new media ( satellites and internet ), recognizing positivity and negativity of new media and factors of protecting from new media negativity. This study depended on the descriptive method with it's two sides : the survey and case study. It relied on observation and the questionnaire as tools to collect data . The study found findings, the most important ones are :

1- It was demonstrated that media methods concerned with youth and educated them methods possessing factors of attraction and objectivity in handling and treatment to increase confidence and credibility in what these methods provide of materials and subjects .

2- It was demonstrated that media methods worked on sharing youth in information work .

3-It was demonstrated that universities support media methods that broadcast subjects calling youth to maintain their identity, disclosing and fighting methods that present materials destroy cultural identity for youth .

The study of Samer Sabry Sadek (2014) ( )entitled " sharing information through social networks at times of crises and it's reflections on Egyptian youth perception of the crisis ". This study aimed at observing and describing the method of face book users sharing for information at times of 
crises in purpose of knowing how to share information through the site when unusual events occurred and recognizing the relationship between the intensity of youth use of face book site at the time of crises, the level of the achieved perception of the crisis through interaction with it's different degrees through the site around the crises " under study ", as well as recognizing the limits and dimensions of media role in which the social networks can perform when crises occur in the society. Finally, recognizing the face book place compared with the conventional methods during crises. This study belongs to the descriptive studies and relies on the survey method. The analytical study sample was represented in a random sample for some profiles that are present on face book site. Posts related with the crises " under study " were analyzed that are : ( petrol crisis, crisis of Port Said stadium events and the crisis of Abbasid events ) over the first six months on 2012 . The field study sample was represented in a purposive sample of (419) items of male and female who use face book site whose ages range between 18:30 years old ( from Big Cairo populations ). The questionnaire and the instrument of analyzing the content represented the study tools. The study concluded a number of findings and the most important ones are :

*The percent of those who use face book site during crises time ( somewhat ) compared with the usual times was ( $53.5 \%$ ), whereas the percent of those who use the site during crises ( always ) compared with usual times was (36.1\%).

*The percent $53.8 \%$ of the sample items confirmed that what it publishes on the site during crises is " of ironical comedy character to reduce the stress resulting from the crisis " as opposed to the percent $46.2 \%$ that publishes of what is " 
serious character by which the crisis developments can be followed ".

*The percent of those who concern ( somewhat ) with following the conventional methods beside following face book during crisis was ( $48 \%$ ), but the percent of those who concern ( always ) was ( $42.8 \%$ ), whereas the percent of those who don't concern with following any conventional methods beside face book site during crises was $(9.2 \%)$.

The study of Lewis , Marieke ( 2012 ) entitled " Electronic sites and the crimes pertaining with the child, reviewing literatures in the field of functioning electronic sites in treating the crimes pertaining with the childhood " The study aimed at recognizing the aspects of benefiting from the electronic activity in treating the crimes pertaining with the child, recognizing classifications of electronic sites in terms of handling childhood specific crimes, exposure for the effects of internet treatment for the crimes pertaining with the childhood on children, reviewing the researches and literatures that concern with treating children crimes in electronic sites .

Method of the study : the present study used the content analysis instrument as a tool for displaying the reality of electronic sites treatment for the crimes of childhood. The study concluded a set of findings, the most important ones are :the study showed that children expose for physical, psychological abuse and negligence from family and this abuse from their mothers is due to mothers exposure for violence .

The study of ( Nitika , An.et al.2012) entitled " the effect of social networks sites in changing youth mind in social issues " . The study aimed at knowing the extent of social 
networks sites effect on the level of youth awareness with social issues and expressing their views towards the flaming issues such as corruption, human rights and girls education . Method : the study used the descriptive method .The sample : it relied on a sample of ( 100) items and their age range between (18: 30 years old ). The instruments : an electronic questionnaire form that was sent on different social networks sites . The study concluded that different social networks sites play a great role in mobilizing the opinion through exchanging the ideas around any issue and youth raise their voice against violating human rights and corruption. The sites demonstrated itself in presenting people ideas of these social issues and the information obtained from people demonstrated that they are more conscious with the social issues depending on face book .

The study of Marina Vastly (2012) entitled " Russian university youth use for social networks sites and recognizing the extent of these methods wealth in providing youth with information " .The study aimed at recognizing Russian university youth use for social networks sites and recognizing the extent of these methods wealth in providing these youth with information. The sample : the study depended on a sample of ( 14 items ) (9) females , ( 5 ) males from university youth whom their ages range between ( 22 : 28 years ) in Saint. Petersburg by using interview tool to get information and the study found several findings including:

1-Social networks sites provide several of personal communication advantages that make it rich with information such as easy and free communication between users , searching for specific information easily and free as well as privatization in communication and the potential of self expression . 
Attitudes of university youth towards the issue of delinquent juvenile children through new media methods: ( a field study on Minia university students(

2-The reasons of youth use for communication sites are represented in : obtaining information, personal communication with family and friends and making use from others experiences .

The second axis : studies deal with attitudes and youth :

The study of Haythem Mohammed Yossef ( 2017 ) entitled : "university youth attitudes towards Saudi national media methods treatment for issues of family violence ". This research aimed at knowing uses and satisfactions of family violence contents receivers in Saudi media methods, through observing their attitudes towards art treatment of it. The researcher used the questionnaire instrument on a sample of ( 400 items ) in the frame of survey method .It is of the descriptive studies. The research found important findings including :

1-There are several negative attitudes of the sample towards treating all Saudi media methods for issues of family violence .

2-The sample acknowledged that social specialists and psychiatrists on the top of information sources of family violence issues .

3-The sample has information about family violence from sources other than Saudi media methods, over it's head Arabic television channels( Arabic internet sites ).

The study of Khalid Hassan Ahmed Luqman (2015 ) entitled " the role of new media in forming social attitudes for Sudanese youth ". This study aims at developing the right scientific and academic description for what the new media caused of a new formation of social attitudes for Sudanese 
youth, detecting the change nature that happens to social attitudes for Sudanese youth as a result of his use for new media methods positively and negatively .The study depended on the descriptive survey method, tools of data collection were used representing in observation, interview and the questionnaire. Programs of statistical analysis were used. The most important findings are :

1-Increasing cultural, knowledge awareness and information for youth, openness to other cultures and societies, communicating cognitions, increasing the technical skill for Sudanese youth and relating it with their society issues.

2-New media weakens family and society role in guiding youth and their care and falls back in public polite with effects of bad use and weakness of the used language .

The study of Hatem Mohammed Atef Abdel Khalik Saad ( 2004 ) entitled "the relationship between adolescents use (14 : 17 years ) for internet and forming their cultural identity a field study ".The study aimed at knowing the relationship between using internet and forming the cultural identity of adolescents in the light of cultural cultivation. In the frame of this study, an organized random sample was selected of ( 494 male and female students ) from secondary stage ) general - private - Azhary technical - industrial commercial - agricultural ). The study found several findings including :

*There are statistically significant differences between students group who uses the internet and their perception of their cultural identity opposed to non users for the internet on behalf of the second group . 
* There are statistically significant differences between male and female and information type in which they search on the internet .

The study of Lin \&Tsai ( 2004 ) entitled " perceptions and attitudes of adolescents from Taiwan towards the internet . The study aimed at recognizing the differences between males and females in their perceptions and attitudes towards the internet. The study sample consisted of ( 636 male and female students ) from high schools at Taiwan. The study found that there are differences in perceptions and attitudes towards the internet between male and female where male see that the internet is an entertainment device and female see the internet as a technological beneficial device .

The third axis - studies of delinquent juvenile children :

The study of Sohair Abdel Menaem (2013 ) entitled : street children and drugs crimes ". This study aimed at the potential of determining the extent of street children exposure for drugs crimes, it must recognize the conditions and circumstances of these children that yield their treatment with drugs, recognizing the child circumstances, his living method in the street, his adjustment in the street, recognizing social and economical conditions that help to spread the phenomenon of street children and their treatment with drugs crimes. The study used more than one method for research ( the analytical descriptive method, the quantitative method that depended on data that were collected through employees guide ).The study relied on a sample representing in different types for each tool of the school instruments that are ( the sample of street children present in government institutions, civil organizations, those who are in the streets and a sample of employees in social institutions ). 
Attitudes of university youth towards the issue of delinquent juvenile children through new media methods: ( a field study on Minia university students(

The study found important findings including : most people who relate with those children are the bully with a percent of $75 \%$ leading to entering in the frame of drugs crimes. The economical factors occupied the first rank as to the circumstances that help to spread the phenomenon of street children and their treatment with drugs crimes .

The study of Khairy Abdel Gayed Darwish (2010) : entitled " the relationship between publishing crimes news and adolescents attitudes towards different crimes ". This study aimed at recognizing the relationship between publishing the crime news and adolescents attitudes towards different crimes from Egyptian press homes and detecting the differences between male and female in reading crime news and education types and the extent of a journalism program effectiveness in enhancing the opposite attitude of the crime for adolescents .

The researcher applied on a sample of Egyptian press that are ElAhram and Alakbar as national journals and regret tears appendix subjected to Algomhuria journal . It was applied on a sample of adolescents from ( 15:17 years ) from male and female in rural and urban of ( 400 items ) from March 2007 to March 2010 at Monofeya governorate . The most important findings : there are statistically significant differences between technical education adolescents and public education adolescents in reading crimes news at Egyptian journals in the positive direction and towards robbery crime and the female are more forthcoming to read crimes news at Egyptian journals and superior than boys in the number of crimes and events and following events news .

Problem of the study : 
By acknowledging the previous studies, it is shown the importance of the role in which new media methods can play representing in ( face book ) in forming university youth knowledge and attitudes towards the phenomenon of delinquent juveniles after reforming society issues for his issues, because problems differ from time to time and from place to place .Now, we are in connection with the hour problem that can shake the nation entity, because the problem of the delinquent juveniles is one of the most dangerous issues and problems that threaten any society entity . It hinders stability and development whether on the national or international level. This study will attempt to recognize the picture of juvenile children in new media methods coverage for this issue and how to share to protect from this phenomenon and knowing university students and youth attitudes towards this issue and his share to protect from this phenomenon and cope it to guarantee the society safety . Feeling the research problem came through reviewing the previous studies and the scientific references, the littleness of the studies that exposed for the research subject through observing the actual reality in the presence of several efforts exerted to operate the university youth role in the society, so the problem of the study was determined in the following question :

" What is the role of new media methods ( face book ) in forming the university youth knowledge and attitudes towards the phenomenon of delinquent juveniles on sites and pages of face book?

Importance of the study :

The importance of the present study is due to a set of the following considerations : 
Attitudes of university youth towards the issue of delinquent juvenile children through new media methods: ( a field study on Minia university students(

1-The study discusses a new subject in the research by which much of the researchers don't pay attention in the field of communication and information. The study examines the role of media in publishing and forming youth knowledge and attitudes towards the problem of delinquent juveniles of multiple and intertwined dimensions between exposure for new media methods representing in face book and its effect on the university youth attitudes and what makes these dimensions intertwined with each other, whereby the study aims at knowing the exchangeable effects between these dimensions .

2-The present study treats a new and modern subject related with the internet and it's reflections on the process of social interaction between university youth, hence, recognizing the role of new media methods specifically ( face book )in the potential of forming university youth knowledge and attitudes towards the subject of delinquent juvenile .

3-The study targets the class of face book for being more usable from university youth for social networks sites, sectors and issues that are covered through it and it's effect on youth attitudes towards these issues .

Thirdly : goals of the study :

The present study seeks to achieve the following sub goals :

1- Recognizing the ratio of new media methods coverage for the issue of delinquent juveniles .

2-Recognizing the ratio of university youth exposure to new media methods and treating their attitudes for the issue of delinquent juveniles issue and the credibility of presenting the issue for university youth . 
Attitudes of university youth towards the issue of delinquent juvenile children through new media methods: ( a field study on Minia university students(

3-Recognizing the general vision of university youth towards new media methods during presenting the issue of delinquent juveniles .

4-Recognizing the differences between university youth towards their attitudes of the problem of delinquent juveniles according to the gender from treating their exposure for new media methods .

Hypotheses of the study :

1-There is a statistically significant relation between the image of delinquent juvenile children in new media methods and university youth attitudes towards it .

2- There is a statistically significant relation between the degree of the subjects follow up for the problem of delinquent juveniles problem through social networks sites and the degree of it's credibility .

3- There is a statistically significant relation between university students in their view for the general picture of delinquent juveniles as the social networks sites present according to the demographic variables ( gender - rural /urban - economical level ) .

4- There is a statistically significant relation between university students in their attitudes towards the problem of delinquent juveniles children according to the demographic variables ( gender - growing up home - economical level ).

Terms of the study :

*Attitude : has several meanings according to the definitions that the researchers in social psychology and information, following some of these definitions : 
Firstly : the linguistic definition ): means the mental preparation for treating an experiment or a situation accompanied by special response habit .

Secondly : the terminological definition : it is the definition of Jordon Alport " it is a state of neurological and psychological preparation or aptitude through person experience and of guidance or dynamic effect on the individual response for all subjects and situations that stimulate this response .

*University youth : they are the age class ( 18:35 years ) who study at Egyptian universities for the stage of BS.C and post graduate studies at Minia university. This is what calls the researcher to develop a definition of youth ( a social slice or sector that has a distinctive status in building society. The procedural definition of youth : an age class of distinctive character and status, has vital biological abilities and psychological and social characteristics making them able to treat with modern technological methods of different types including new media methods and the effect of these methods on them .

*Delinquent juveniles :

$\mathrm{He}$ is the young who doesn't exceed the age that the law determines of adult age and commits an act which the law considers a crime such as robbery, murder and rape and they are those commit acts which the penal law punishes .

* New media methods: it is the method that provides interactivity, non -mass and asynchrony that are the methods that depend on using technology of the satellite and 
technology of interactive communication and it's different applications, in front of them are the internet, satellites and the mobile.

The procedural definition : a set of applications " digital communication, electronic publishing of different types, digital television and internet, using personal and portable devices .

*Type of the study :

This study belongs to descriptive studies. They are the studies that aim at recognizing the effect of new media methods on university youth in forming university youth knowledge and attitudes towards the phenomenon of delinquent juveniles and applying the access of cultural cultivation on this study Method of the study :

The study uses the information survey method .It seeks to survey university youth from male and female and study the mutual relationship to obtain conclusions to study the relation between variables of youth attitudes and the role of exposure for new media methods by using the median variables .

Community of the study:

Community of the study is represented in a number of Minia university students at theoretical and practical faculties and all educational stages from ( male and female ) and analogue with different slices of Egyptian society and is represented from rural and urban students .

*Sample of the study : 
Attitudes of university youth towards the issue of delinquent juvenile children through new media methods: ( a field study on Minia university students(

The sample of this study is represented in a field sample . The study was conducted on a sample of (400) items from Minia university students with it's different educational stages whose ages range between (17: 22 years ) who use new media methods. The study was conducted on the sample where the researcher considers rural and urban representation ( from Minia university students ) by using a random sample of male and female at Minia university given the demographical characteristics for the sample items ( age gender - housing " rural - urban " - educational level - the study type " practical - theoretical " )

Tools of data collection :

The present study was applied by using the questionnaire form :

Findings of the study :

Table (1) shows the ratio of the subjects use for social

\begin{tabular}{|c|c|c|c|c|c|c|}
\hline \multirow{2}{*}{$\begin{array}{c}\text { The ratio } \\
\text { of use }\end{array}$} & \multicolumn{4}{|c|}{ The sample } & Total & \multirow{2}{*}{$\begin{array}{c}\text { The } \\
\text { percentage }\end{array}$} \\
\cline { 2 - 6 } & \multicolumn{2}{|c|}{ Male } & \multicolumn{2}{c|}{ Female } & \multirow{2}{*}{ Frequency } & \\
\cline { 2 - 6 } & $\mathrm{F}$ & $\%$ & $\mathrm{~F}$ & $\%$ & & \\
\hline Always & 144 & $72 \%$ & 12 & $62 \%$ & 268 & $67 \%$ \\
\hline Sometimes & 54 & $72 \%$ & 68 & $34 \%$ & 122 & $30.5 \%$ \\
\hline No & 2 & $1 \%$ & 8 & $4 \%$ & 10 & $2.5 \%$ \\
\hline Total & 200 & $100 \%$ & 200 & 100 & 400 & $100 \%$ \\
\hline
\end{tabular}

networks sites

Data were extracted and analyzed statistically by using frequency coefficients and percentages . 
Attitudes of university youth towards the issue of delinquent juvenile children through new media methods: ( a field study on Minia university students(

It is shown from the previous table that the ratio of the subjects use for social networks is represented in (always ) with a percent of ( $67 \%$ ) in the first order, then (sometimes) with a percent of $30.5 \%$ in the second order and finally (rarely) in the third order with a percent of $(2.5 \%)$.

These findings accord to the findings of the previous studies represented in the study of Ahmed Refaay (2014) that found that university youth use for social networks sites with a percent of (54.5\%) from the sample individuals use " always " social networks sites through the internet and the percent $37 \%$ sometimes use it .

From previously mentioned and the findings of the present study and it's compatibility with the previous studies findings, the researcher sees that social networks sites are of fundamental need, shouldn't avoid and neglect it because of the subsequent development in technicalities and instruments and methods used in these networks, it's spread and quick effect than any other method. Youth can access the internet and social networks sites to provide the best services, draw information, news, entertainment and leisure according to the desire of every individual in the society, sharing and forming a public opinion towards political and social issues and help discussion between university youth and others about the raised issues, so it is an outlet for youth and society that can't be neglected .

\begin{tabular}{|c|c|c|c|c|c|c||}
\hline \multirow{2}{*}{$\begin{array}{c}\text { Electronic } \\
\text { sites }\end{array}$} & \multicolumn{4}{|c|}{ The sample } & \multicolumn{2}{c|}{ Total } \\
\cline { 2 - 7 } & \multicolumn{2}{|c|}{ Male } & \multicolumn{2}{c|}{ Female } & \multirow{2}{*}{ Frequency } & $\begin{array}{c}\text { The } \\
\text { percentage }\end{array}$ \\
\cline { 2 - 7 } & $\mathrm{F}$ & $\%$ & $\mathrm{~F}$ & $\%$ & & $97.4 \%$ \\
\hline Face book & 193 & $97.4 \%$ & 187 & $97.3 \%$ & 380 & 97 \\
\hline
\end{tabular}


Attitudes of university youth towards the issue of delinquent juvenile children through new media methods: ( a field study on Minia university students(

\begin{tabular}{|c|c|c|c|c|c|c||}
\hline Twitter & 70 & $35.3 \%$ & 82 & $42.7 \%$ & 152 & $38.9 \%$ \\
\hline LinkedIn & 13 & $6.5 \%$ & 13 & $6.7 \%$ & 26 & $6.6 \%$ \\
\hline Google + & 72 & $36.3 \%$ & 70 & $36.4 \%$ & 142 & $36.4 \%$ \\
\hline Instagram & 93 & $46.9 \%$ & 85 & $44.2 \%$ & 178 & $45.6 \%$ \\
\hline Flickr & 16 & $8.1 \%$ & 5 & $2.6 \%$ & 21 & $5.4 \%$ \\
\hline MySpace & 4 & $2.1 \%$ & 3 & $1.5 \%$ & 7 & $1.8 \%$ \\
\hline Benz East & 11 & $5.5 \%$ & 4 & $2.1 \%$ & 15 & $3.8 \%$ \\
\hline YouTube & 99 & $50 \%$ & 116 & $60.4 \%$ & 215 & $55.1 \%$ \\
\hline
\end{tabular}

Table (2) : showing social networks in which the subjects have special accounts on it .

*The subject can select more than one alternative , $n=.390$

**Data was extracted and analyzed it statistically by using frequency coefficients and percentages .

It is shown from the previous table that face book site came in the front of electronic sites that the subjects have a personal account with a percent of $97.4 \%$, then YouTube in the second order with a percent of $55.1 \%$ and the final order came on behalf of MySpace site with a percent of $1.8 \%$.

The finding of the previous table is due to that face book sites are characterized with several privileges including friendships, sharing as well as the effluent of it's users, followed by YouTube site .

The researcher sees that the increase in using face book and YouTube between university youth is due to the development in these methods and it's smallness arrives to the degree that it can be moved to any place including the mobile, where the individual can access to these sites easily and at any place and any time. And because these methods became a source of 
Attitudes of university youth towards the issue of delinquent juvenile children through new media methods: ( a field study on Minia university students(

information about different issues and are used to exchange , share and form a public opinion for issues .

Table (3) : illustrating that social networks are a source of information for the subjects

\begin{tabular}{|c|c|c|c|c|c|c||}
\hline \multirow{3}{*}{ Evaluation } & \multicolumn{4}{|c|}{ The sample } & \multicolumn{2}{c|}{ Total } \\
\cline { 2 - 5 } & \multicolumn{2}{|c|}{ Male } & \multicolumn{2}{c|}{ Female } & \multirow{2}{*}{ Frequency } & $\begin{array}{c}\text { The } \\
\text { percentage }\end{array}$ \\
\cline { 2 - 5 } & $\mathrm{F}$ & $\%$ & $\mathrm{~F}$ & $\%$ & & $84.8 \%$ \\
\hline Yes & 179 & $90.3 \%$ & 152 & $79.2 \%$ & 331 & $15.2 \%$ \\
\hline No & 19 & $4.8 \%$ & 40 & $20.8 \%$ & 59 & $100 \%$ \\
\hline Total & 198 & $100 \%$ & 192 & $100 \%$ & 390 & \\
\hline
\end{tabular}

Data was extracted and analyzed it statistically by using frequency coefficients and percentages .

It is shown from the previous table that $84.8 \%$ of the subjects see that social networks are source of information, while $15.2 \%$ of the subjects see the opposite

Table ( 4 ) displaying the reasons why social networks are not a source of information

\begin{tabular}{|c|c|c|c|c|c|c||}
\hline \multirow{2}{*}{ Reasons } & \multicolumn{4}{|c|}{ The sample } & \multicolumn{2}{c|}{ Total } \\
\cline { 2 - 7 } & \multicolumn{2}{|c|}{ Male } & \multicolumn{2}{c|}{ Female } & Frequency & $\begin{array}{c}\text { The } \\
\text { percentage }\end{array}$ \\
\cline { 2 - 7 } & $\mathrm{F}$ & $\%$ & $\mathrm{~F}$ & $\%$ & 72 & $59.3 \%$ \\
\hline $\begin{array}{c}\text { Knowledge } \\
\text { are not new }\end{array}$ & 8 & $13.5 \%$ & 72 & $\begin{array}{c}45.7 \\
\%\end{array}$ & 35 & $96.6 \%$ \\
\hline $\begin{array}{c}\text { Undocument } \\
\text { ed }\end{array}$ & 19 & $32.2 \%$ & 83 & $\begin{array}{c}64.4 \\
\%\end{array}$ & 57 & $23.7 \%$ \\
\hline Many & 4 & $6.7 \%$ & 10 & 16.9 & 14 & \\
\hline
\end{tabular}


Attitudes of university youth towards the issue of delinquent juvenile children through new media methods: ( a field study on Minia university students(

\begin{tabular}{|c|c|c|c|c|c|c||}
\hline $\begin{array}{c}\text { rumors on } \\
\text { social } \\
\text { networks }\end{array}$ & & & & $\%$ & & \\
\hline $\begin{array}{c}\text { Inaccurate } \\
\text { knowledge }\end{array}$ & 1 & $1.6 \%$ & 3 & $5.1 \%$ & 4 & $6.7 \%$ \\
\hline $\begin{array}{c}\text { Providing } \\
\text { superficial } \\
\text { and trivia } \\
\text { information }\end{array}$ & 0 & $0 \%$ & 0 & $0 \%$ & 0 & $0 \%$ \\
\hline
\end{tabular}

*The subject can select more than one alternative, $\mathrm{n}=.59$

- Data was extracted and analyzed it statistically by using frequency coefficients and percentages .

It is shown from the previous table that $96.6 \%$ of the sample individuals don't consider social networks a source of information for being undocumented and the second reason was ( knowledge are not new ) with a percent of $59.3 \%$ and in the final order (inaccurate knowledge ).

Table (5) :showing the extent of the subjects use for private electronic sites that present the child issues

\begin{tabular}{|c|c|c|c|c|c|c||}
\hline \multirow{2}{*}{$\begin{array}{c}\text { The extent of } \\
\text { use }\end{array}$} & \multicolumn{4}{|c|}{ The sample } & \multicolumn{2}{c||}{ Total } \\
\cline { 2 - 7 } & \multicolumn{2}{|c|}{ Male } & \multicolumn{2}{c|}{ Female } & Frequency & $\begin{array}{c}\text { The } \\
\text { percentage }\end{array}$ \\
\cline { 2 - 7 } & $\mathrm{F}$ & $\%$ & $\mathrm{~F}$ & $\%$ & & $11.4 \%$ \\
\hline Yes / always & 28 & $14.1 \%$ & 16 & $8.3 \%$ & 44 & $62.8 \%$ \\
\hline Somewhat & 151 & $76.2 \%$ & 94 & $\begin{array}{c}48.9 \\
\%\end{array}$ & 245 & \\
\hline
\end{tabular}


Attitudes of university youth towards the issue of delinquent juvenile children through new media methods: ( a field study on Minia university students(

\begin{tabular}{|c|c|c|c|c|c|c|}
\hline No & 19 & $9.6 \%$ & 82 & $\begin{array}{c}42.7 \\
\%\end{array}$ & 101 & 25.8 \\
\hline Total & 198 & $100 \%$ & 192 & $100 \%$ & 390 & $100 \%$ \\
\hline
\end{tabular}

Data was extracted and analyzed it statistically by using frequency coefficients and percentages .

It is shown from the previous table that most subjects use the private electronic sites that present the child issues ( somewhat ) with a percent of $92.8 \%$, then ( those who don't use it ) with a percent of $25.8 \%$ and in the final order those who use the sites ( yes / always ) with a percent of $11.4 \%$.

This interprets that electronic sites for the research sample were used greatly in the sites of entertainment, leisure , E. mail, sport and art sites, information retrieval and social communication because of the subjects age class .

Table (6) : displaying how to recognize electronic sites of childhood and it's delinquency

\begin{tabular}{|c|c|c|c|c|c|c||}
\hline \multirow{2}{*}{ Mechanisms } & \multicolumn{4}{|c|}{ The sample } & \multicolumn{2}{c|}{ Total } \\
\cline { 2 - 7 } & \multicolumn{2}{|c|}{ Male } & \multicolumn{2}{c|}{ Female } & Frequency & $\begin{array}{c}\text { The } \\
\text { percentage }\end{array}$ \\
\cline { 2 - 5 } & $\mathrm{F}$ & $\%$ & $\mathrm{~F}$ & $\%$ & & $26.4 \%$ \\
\hline By chance & 29 & $14.6 \%$ & 74 & $38.5 \%$ & 103 & $10.5 \%$ \\
\hline $\begin{array}{c}\text { Search } \\
\text { deliberately }\end{array}$ & 26 & $13.1 \%$ & 15 & $7.8 \%$ & 41 & \\
\hline
\end{tabular}


Attitudes of university youth towards the issue of delinquent juvenile children through new media methods: ( a field study on Minia university students(

\begin{tabular}{|c|c|c|c|c|c|c||}
\hline $\begin{array}{c}\text { From friends } \\
\text { and } \\
\text { Acquaintance } \\
\mathrm{s}\end{array}$ & 11 & $5.5 \%$ & 0 & $0 \%$ & 11 & $2.8 \%$ \\
\hline $\begin{array}{c}\text { Other media } \\
\text { methods }\end{array}$ & 7 & $3.5 \%$ & 0 & $0 \%$ & 7 & $1.8 \%$ \\
\hline \begin{tabular}{c} 
Internet sites \\
\hline $\begin{array}{c}\text { Arabic and } \\
\text { Egyptian } \\
\text { satellites }\end{array}$
\end{tabular} & 1 & $0.5 \%$ & 0 & $0 \%$ & 1 & $0.2 \%$ \\
\hline $\begin{array}{c}\text { Through } \\
\text { advertisement } \\
\text { s in media } \\
\text { methods }\end{array}$ & 1 & $0.5 \%$ & 0 & $0 \%$ & 1 & $0.2 \%$ \\
\hline
\end{tabular}

* The subject can select more than one alternative, $\mathrm{n}=.39$

- Data was extracted and analyzed it statistically by using frequency coefficients and percentages .

It is shown from the previous table that the $26.4 \%$ of the subjects recognize the electronic sites of childhood and it's delinquency by chance, then search it deliberately with a percent of $10.5 \%$ and in the final order internet sites, Arabic satellites , advertisements in media methods with a percent of $0.2 \%$.

Table (7) : illustrating the ratio of the subjects follow up for the child issues on their favorite site . 
Attitudes of university youth towards the issue of delinquent juvenile children through new media methods: ( a field study on Minia university students(

\begin{tabular}{|c|c|c|c|c|c|c||}
\hline \multirow{2}{*}{$\begin{array}{c}\text { The ratio of } \\
\text { follow up }\end{array}$} & \multicolumn{3}{|c|}{ The sample } & \multicolumn{2}{c|}{ Total } \\
\cline { 2 - 7 } & \multicolumn{2}{|c|}{ Male } & \multicolumn{2}{c|}{ Female } & Frequency & $\begin{array}{c}\text { The } \\
\text { percentage }\end{array}$ \\
\cline { 2 - 7 } & $\mathrm{F}$ & $\%$ & $\mathrm{~F}$ & $\%$ & & $11.5 \%$ \\
\hline Every day & 23 & $11.8 \%$ & 22 & $11.4 \%$ & 45 & $8.7 \%$ \\
\hline $\begin{array}{c}\text { From three to } \\
\text { five days } \\
\text { weekly }\end{array}$ & 24 & $12.1 \%$ & 10 & $5.3 \%$ & 34 & $14.6 \%$ \\
\hline $\begin{array}{c}\text { Less than } \\
\text { three days }\end{array}$ & 35 & $17.7 \%$ & 22 & $11.4 \%$ & 57 & $25.6 \%$ \\
\hline $\begin{array}{c}\text { Once every } \\
\text { week }\end{array}$ & 48 & $24.2 \%$ & 50 & $26.1 \%$ & 100 & $40 \%$ \\
\hline $\begin{array}{c}\text { Once every } \\
\text { month }\end{array}$ & 68 & $34.4 \%$ & 88 & $45.8 \%$ & 156 & $100 \%$ \\
\hline \begin{tabular}{c} 
Total \\
\hline
\end{tabular} & 198 & $100 \%$ & 192 & $100 \%$ & 390 & \\
\hline
\end{tabular}

Data was extracted and analyzed it statistically by using frequency coefficients and percentages .

It is shown from the previous table that the ratio of the subjects follow up for the child issues on their favorite site represents ( once every month ) with a percent of $40 \%$, then ( once every week ( with a percent of $25.6 \%$ and in the final order from three to five days weekly with a percent of $8.7 \%$.

The researcher sees through presenting findings of the previous studies and the present study that university 
Attitudes of university youth towards the issue of delinquent juvenile children through new media methods: ( a field study on Minia university students(

youth follow up for child sites monthly interprets youth interest in other social, sport, political, cultural and scientific sites and littleness of integrating the childhood issues on daily sites whether news or cultural or leisure or social and that some sites require a certain age to participate the member .

Table (8) :showing the reasons of participating on your favorite site in issues of delinquent juveniles .

\begin{tabular}{|c|c|c|c|c|c|c||}
\hline \multirow{2}{*}{ Reasons } & \multicolumn{3}{|c|}{ The sample } & \multicolumn{2}{c|}{ Total } \\
\cline { 2 - 6 } & \multicolumn{2}{|c|}{ Male } & \multicolumn{2}{c|}{ Female } & Frequency & $\begin{array}{c}\text { The } \\
\text { percentage }\end{array}$ \\
\cline { 2 - 6 } & $\mathrm{F}$ & $\%$ & $\mathrm{~F}$ & $\%$ & & 45.3 \\
\hline $\begin{array}{c}\text { To } \\
\text { acknowledge } \\
\text { what is new on } \\
\text { the internet }\end{array}$ & 83 & 41.9 & 94 & 48.9 & 177 & $11.8 \%$ \\
\hline $\begin{array}{c}\text { The content of } \\
\text { these sites are } \\
\text { of my interests }\end{array}$ & 23 & $\begin{array}{c}11.6 \\
\%\end{array}$ & 32 & 11.9 & 46 & $9.2 \%$ \\
\hline $\begin{array}{c}\text { Allowing } \\
\text { different and } \\
\text { varied forms of } \\
\text { interactivity } \\
\text { with the public }\end{array}$ & 25 & $\begin{array}{c}12.6 \\
\%\end{array}$ & 11 & $5.7 \%$ & 36 & $18.4 \%$ \\
\hline $\begin{array}{c}\text { Present a great } \\
\text { deal of news } \\
\text { materials and }\end{array}$ & 39 & $\begin{array}{c}19.6 \\
\%\end{array}$ & 33 & 11.9 & 72 & \\
\hline
\end{tabular}


Attitudes of university youth towards the issue of delinquent juvenile children through new media methods: ( a field study on Minia university students(

\begin{tabular}{|c|c|c|c|c|c|c|}
\hline information & & & & & & \\
\hline $\begin{array}{l}\text { Littleness of } \\
\text { the information }\end{array}$ & 22 & $\begin{array}{c}11.1 \\
\%\end{array}$ & 7 & $3.6 \%$ & 29 & $7.4 \%$ \\
\hline $\begin{array}{l}\text { Providing too } \\
\text { much space to } \\
\text { practice } \\
\text { expression } \\
\text { freedom of } \\
\text { opinions and } \\
\text { ideas }\end{array}$ & 32 & $\begin{array}{c}16.1 \\
\%\end{array}$ & 33 & $\begin{array}{c}17.2 \\
\%\end{array}$ & 65 & $16.6 \%$ \\
\hline $\begin{array}{l}\text { The potential } \\
\text { of watching old } \\
\text { programs and } \\
\text { dialogues of } \\
\text { the problem } \\
\text { through an } \\
\text { archive. }\end{array}$ & 21 & $\begin{array}{c}10.6 \\
\%\end{array}$ & 22 & $\begin{array}{c}11.4 \\
\%\end{array}$ & 43 & $11 \%$ \\
\hline $\begin{array}{l}\text { Programs } \\
\text { available on } \\
\text { the site }\end{array}$ & 39 & $\begin{array}{c}19.7 \\
\%\end{array}$ & 29 & $\begin{array}{c}15.1 \\
\%\end{array}$ & 68 & $17.4 \%$ \\
\hline $\begin{array}{l}\text { Dealing with } \\
\text { new subjects } \\
\text { that } \\
\text { conventional } \\
\text { media methods } \\
\text { don't present }\end{array}$ & 25 & $\begin{array}{c}12.6 \\
\%\end{array}$ & 82 & $\begin{array}{c}14.5 \\
\%\end{array}$ & 53 & $13.5 \%$ \\
\hline $\begin{array}{l}\text { Listening to it } \\
\text { any where } \\
\text { easily }\end{array}$ & 27 & $\begin{array}{c}13.6 \\
\%\end{array}$ & 72 & 14 & 54 & $13.8 \%$ \\
\hline
\end{tabular}


Attitudes of university youth towards the issue of delinquent juvenile children through new media methods: ( a field study on Minia university students(

\begin{tabular}{|c|c|c|c|c|c|c||}
\hline $\begin{array}{c}\text { Benefiting } \\
\text { from advices } \\
\text { and } \\
\text { information in } \\
\text { which it } \\
\text { includes }\end{array}$ & 0 & $0 \%$ & 0 & $0 \%$ & 0 & $0 \%$ \\
\hline $\begin{array}{c}\text { For developing } \\
\text { my personal } \\
\text { skills }\end{array}$ & 0 & $0 \%$ & 0 & $0 \%$ & 0 & $0 \%$ \\
\hline
\end{tabular}

* The subject can select more than one alternative, $\mathrm{n}=.390$

- Data was extracted and analyzed it statistically by using frequency coefficients and percentages .

It is shown from the previous table that the reasons of sharing on your favorite site in delinquency juveniles issues represent knowing what is new on the internet with a percent of $45.3 \%$, then( present a great deal of news materials and information) in the second order with a percent of $18.4 \%$ and the final order was on behalf of the information littleness with a percent of $7.4 \%$.

The previous finding interprets that the issues of delinquent juveniles are of the issues that aren't included in the priorities of university youth because it is a problem by which a certain class and authorities concern with and that social networks sites and it's forms neglect certain problems and concern with social, leisure, entertainment issues for youth and the rest of society classes. So, the responsible authorities of delinquent juveniles institutions must find sites for them on social networks . 
Attitudes of university youth towards the issue of delinquent juvenile children through new media methods: ( a field study on Minia university students(

Table (9) : illustrating the general evaluation for presenting the favorite subjects site for issues of delinquent juvenile children

\begin{tabular}{|c|c|c|c|c|c|c|}
\hline \multirow[t]{3}{*}{ Evaluation } & \multicolumn{4}{|c|}{ The sample } & \multicolumn{2}{|c|}{ Total } \\
\hline & \multicolumn{2}{|c|}{ Male } & \multicolumn{2}{|c|}{ Female } & \multirow{2}{*}{$\begin{array}{c}\text { Frequenc } \\
\mathrm{y}\end{array}$} & \multirow{2}{*}{$\begin{array}{c}\text { The } \\
\text { percentage }\end{array}$} \\
\hline & $\mathrm{F}$ & $\%$ & $\mathrm{~F}$ & $\%$ & & \\
\hline Excellent & 18 & $9.1 \%$ & 10 & $5.2 \%$ & 28 & $7.2 \%$ \\
\hline Good & 103 & $52 \%$ & 47 & $\begin{array}{c}24.4 \\
\%\end{array}$ & 150 & $38.5 \%$ \\
\hline Moderate & 59 & $29.8 \%$ & 46 & $\begin{array}{c}23.9 \\
\%\end{array}$ & 105 & $26.9 \%$ \\
\hline Weak & 18 & $9.1 \%$ & 89 & $\begin{array}{c}46.3 \\
\%\end{array}$ & 107 & $27.4 \%$ \\
\hline Total & 198 & $100 \%$ & 192 & $100 \%$ & 390 & $100 \%$ \\
\hline
\end{tabular}

- Data was extracted and analyzed it statistically by using frequency coefficients and percentages .

It is shown from the previous table that the general evaluation for the favorite subjects site presentation for 
Attitudes of university youth towards the issue of delinquent juvenile children through new media methods: ( a field study on Minia university students(

the issues of delinquent juvenile children is represented in (good) with a percent of $38.5 \%$ in the first order, then ( weak ) in the second order with a percent of $27.4 \%$ and finally ( excellent ) with a percent of $7.2 \%$.

Through analyzing the previous data, it is shown that the finding is a logical one, because the issue of delinquent juvenile children is not an important issue for the subjects , because the sample individuals have important issues occupying their interest such as the political, social and leisure issues and that social networks sites possess social relations, exchange messages with friends and write comments .

Table (10) : displaying the effect of using the favorite electronic sites on the direction towards the problem of delinquent juveniles .

\begin{tabular}{|c|c|c|c|c|c|c||}
\hline \multirow{3}{*}{ Evaluation } & \multicolumn{3}{|c|}{ The sample } & \multicolumn{2}{c|}{ Total } \\
\cline { 2 - 5 } & \multicolumn{2}{|c|}{ Male } & \multicolumn{2}{c|}{ Female } & Frequency & $\begin{array}{c}\text { The } \\
\text { percentage }\end{array}$ \\
\cline { 2 - 5 } & $\mathrm{F}$ & $\%$ & $\mathrm{~F}$ & $\%$ & & \\
\hline Always & 38 & $19.2 \%$ & 23 & $12 \%$ & 61 & $15.6 \%$ \\
\hline $\begin{array}{c}\text { Sometime } \\
\text { s }\end{array}$ & 134 & $67.7 \%$ & 116 & 60.4 & 250 & $64.1 \%$ \\
\hline
\end{tabular}


Attitudes of university youth towards the issue of delinquent juvenile children through new media methods: ( a field study on Minia university students(

\begin{tabular}{||c|c|c|c|c|c|c||}
\hline Rarely & 26 & $13.1 \%$ & 53 & $\begin{array}{c}27.6 \\
\%\end{array}$ & 79 & $20.3 \%$ \\
\hline Total & 198 & $100 \%$ & 192 & $100 \%$ & 390 & $100 \%$ \\
\hline
\end{tabular}

- Data was extracted and analyzed it statistically by using frequency coefficients and percentages .

It is shown from the previous table that the effect of using the favorite electronic sites on the direction towards the problem of the delinquent juveniles is represented in ( sometimes ) with a percent of $64.1 \%$ in the first order , then ( rarely ) with a percent of $20.3 \%$ and the final order was on behalf of ( always ) with a percent of $15.6 \%$.

The previous finding of the present study is a valid one and this is shown through the favorite sites the youth " the study sample " selected, that are leisure , entertainment, social, sport and political sites that don't present children issues whether the positive or the negative ones on these sites but with a very minimum percent because of age stage variance . So, the researcher sees the necessity of interested in children issues whether the positive or the negative ones including the issues of delinquent juvenile children on social networks sites so that the society individuals in general among them are university youth ( the study sample ) can stand together to solve these issues and eliminate them to serve the society by putting moulds and semi daily news on social networks sites, increasing youth awareness with these issues on these sites. 
Attitudes of university youth towards the issue of delinquent juvenile children through new media methods: ( a field study on Minia university students(

Table (11 ) :displaying the extent of favorite social networks success in covering the problem of delinquent juveniles .

\begin{tabular}{|c|c|c|c|c|c|c|}
\hline \multirow{2}{*}{ Alternatives } & \multicolumn{3}{|c|}{ The sample } & \multicolumn{2}{c|}{ Total } \\
\cline { 2 - 7 } & \multicolumn{2}{|c|}{ Male } & \multicolumn{2}{c|}{ Female } & Frequency & \multicolumn{2}{c|}{$\begin{array}{c}\text { The } \\
\text { percentage }\end{array}$} \\
\hline \hline $\begin{array}{c}\text { a large } \\
\text { extent }\end{array}$ & 37 & $18.7 \%$ & 11 & $5.7 \%$ & 48 & $12.3 \%$ \\
\hline $\begin{array}{c}\text { Succeed } \\
\text { somewhat }\end{array}$ & 136 & $68.7 \%$ & 105 & $\begin{array}{c}54.7 \\
\%\end{array}$ & 241 & $61.8 \%$ \\
\hline $\begin{array}{c}\text { Not achieve } \\
\text { any success }\end{array}$ & 25 & $12.6 \%$ & 76 & $\begin{array}{c}39.6 \\
\%\end{array}$ & 101 & $25.9 \%$ \\
\hline $\begin{array}{c}\text { Total } \\
\text { Succed to }\end{array}$ & 198 & $100 \%$ & 129 & $\begin{array}{c}100 \\
\%\end{array}$ & 390 & $100 \%$ \\
\hline
\end{tabular}

- Data was extracted and analyzed it statistically by using frequency coefficients and percentages .

It is shown from the previous table that the favorite social networks sites succeed ( somewhat) in covering the problem of delinquent juveniles with a percent of $61.8 \%$ 
Attitudes of university youth towards the issue of delinquent juvenile children through new media methods: ( a field study on Minia university students(

in the first order, then not achieving any success with a percent of $25.9 \%$ in the second order and in the final order ( succeed to a large extent with a percent of $12.3 \%$.

Verifying the study hypotheses :

* There are statistically significant differences between university youth in their direction towards the problem of delinquent juvenile children according to the demographic variables ( gender - growing up home - the economical level ).

Table (12 ) : illustrating the differences significance between male and female in their direction towards the problem of delinquent juvenile children $n=390$

\begin{tabular}{|c|c|c|c|c|c|c||}
\hline Variables & \multicolumn{2}{|c|}{ Male $\mathrm{n}=198$} & \multicolumn{2}{|c|}{$\begin{array}{c}\text { Female } \\
\mathrm{n}=192\end{array}$} & T value & $\begin{array}{c}\text { Significan } \\
\text { ce type }\end{array}$ \\
\cline { 2 - 5 } & $\mathrm{M}$ & $\mathrm{SD}$ & $\mathrm{M}$ & $\mathrm{SD}$ & & \\
\hline $\begin{array}{c}\text { Their attitudes } \\
\text { towards the } \\
\text { problem of } \\
\text { delinquent } \\
\text { juvenile children }\end{array}$ & 2.06 & 0.56 & 1.86 & 0.62 & $* * 3.31$ & $\begin{array}{c}\text { Statisticall } \\
\mathrm{y} \\
\text { significant }\end{array}$ \\
\hline
\end{tabular}

- Test of differences significance was extracted by using t-test.

It is shown from the findings of the previous table : 
Attitudes of university youth towards the issue of delinquent juvenile children through new media methods: ( a field study on Minia university students(

It was ascertained the validity of the hypothesis partially, where it was shown that there are statistically significant differences between male and female in their attitude towards the problem of delinquent juvenile children on behalf of male .It was verified social networks sites coverage for the issue with varied percents and the proof is university youth attitudes towards the issue and male superiority on female in their attitude towards the crisis, because male perceived the issue danger and it's effect on society and a proof of male follow up for social sites than female, his reliance on recognizing the most important news and issues from these sites than the conventional media methods in which the female rely on in knowing the most important news and issues than male as a result of their presence in homes .

(b) Differences according to grown up home :

Table ( 13 ): showing the differences significance between rural and urban in their attitudes towards the problem of delinquent juvenile children $n=390$

\begin{tabular}{|l|l|l|l|l|l|l||}
\hline Variables & \multicolumn{2}{|l|}{ Urban $\mathrm{n}=151$} & \multicolumn{2}{l|}{ Rural $\mathrm{n}=239$} & T value & $\begin{array}{l}\text { Significance } \\
\text { type }\end{array}$ \\
\cline { 2 - 6 } & $\mathrm{M}$ & $\mathrm{SD}$ & $\mathrm{M}$ & $\mathrm{SD}$ & & \\
\hline $\begin{array}{r}\text { Their attitudes } \\
\text { towards } \\
\text { problem } \\
\text { delinquent juvenile } \\
\text { children }\end{array}$ & 1.94 & 0.61 & 1.97 & 0.60 & 0.55 & $\begin{array}{l}\text { Non } \\
\text { significance }\end{array}$ \\
\hline
\end{tabular}


Attitudes of university youth towards the issue of delinquent juvenile children through new media methods: ( a field study on Minia university students(

- Test of differences significance was extracted by using t-test coefficient .

It is shown from the findings of the previous table :*

It was not ascertained the validity of the hypothesis partially, where it was shown that there are no statistically significant differences between rural and urban in their attitude towards the problem of delinquent juvenile children .

* The finding of the present hypothesis of the study can be interpreted that youth attitudes ( the study sample ) of the delinquent juveniles issue are equal in the attitudes between rural and urban, all perceive the issue danger on the society and all have the aptitude to participate in solving it and that the issue presentation is not directed for a certain class, not related with a geographical region .So, youth direct towards the crisis without restricting to geographical limits . Urban perceives the danger and rural also perceives the danger .

(c) Differences according to incomes: 


\begin{tabular}{|l|l|l|l|l|l|l||}
\hline Variables & $\begin{array}{l}\text { Varianc } \\
\text { e } \\
\text { source }\end{array}$ & Square sum & $\begin{array}{l}\text { Freedom } \\
\text { degree }\end{array}$ & $\begin{array}{l}\text { Mean } \\
\text { square }\end{array}$ & F & $\begin{array}{l}\text { Significance } \\
\text { type }\end{array}$ \\
\cline { 2 - 5 } & $\begin{array}{l}\text { Betwee } \\
\mathrm{n} \\
\text { groups }\end{array}$ & 0.93 & 3 & 0.031 & & \\
\hline $\begin{array}{l}\text { The } \\
\text { subjects } \\
\text { attitudes } \\
\text { towards the } \\
\text { problem of } \\
\text { delinquent } \\
\text { juvenile } \\
\text { children }\end{array}$ & $\begin{array}{l}\text { Intra } \\
\text { groups }\end{array}$ & 0.61 & 1.97 & 0.60 & Non \\
significance
\end{tabular}

Table (14 ) : displaying one way variance analysis between different incomes ( less than 1000 pounds, more than 2000 pounds, from 3000 to 5000 pounds, more than 5000 pounds ) in their attitude towards the problem of delinquent juvenile children $n=(390)$.

- Test of differences significance was extracted by using one way variance analysis( ANOVA) .

It is shown from the findings of the previous table :* 
*This finding can be interpreted that youth attitudes towards the issue through presenting the problem of delinquent juvenile children on electronic sites without a difference between income or an economic level indicating university youth sense ( the study sample )with the issue danger, resolve and eliminate it through any form of attitude forms towards it or participating in electronic media methods .

* It was not ascertained the validity of the hypothesis partially, where it was shown that there are no statistically significant differences between different incomes, less than 1000 pounds, more than 2000 pounds , from 3000 to 5000 pounds, more than 5000 pounds ) in their attitude towards the problem of delinquent juvenile children.

Those in the electronic sites must exploit the opportunity of youth attitudes towards the issue of delinquent juvenile children by presenting the issue without considering the variable of economic level into account . Exploiting youth positive attitudes by using them in producing, publishing materials and news on electronic sites . Exploiting their attitudes towards the issue during preparing laws and legislations for delinquent juvenile children, making them participate in institutions of delinquent juvenile children and eliminating the crisis for it's danger on the society .

Recommendations :

*Developing an appropriate media plan in which a suitable time and place are selected for different types of news during addressing youth with issues of the society to draw their attitudes towards it. 
*Interested in new media researches and public particularly university youth and society issues through developing a program plan appropriate with their needs given that these researches include all classes in a balanced way, especially youth, media methods, childhood problems with all it's classes and types .

*Looking at the internet as an effective media method and plays a basic role in changing youth attitudes and behaviors towards some phenomena that is delinquent juveniles on the internet .

*Investing social networks sites, making use of it's renewed services in addressing the phenomenon of delinquent juveniles, educating youth with it's risks on Egyptian society .

*Opening free dialogue channels with university youth who are users of the internet to know the reasons of some resort to affiliate to sites and pages that concern with juveniles issues, educating the problem of delinquent juveniles in Egypt and Arabic home, the bases of dealing with it particularly in new media methods and the internet applications .

* Emphasizing the role of university youth in media awareness with society issues particularly the issues of delinquent juveniles, especially in the field of communication and media uses for the internet, where the study showed the positive effect of social networks sites in educating university youth abilities on communication and cultural understanding, spreading positive ideas that support this attitude and encouraging youth to establish the constructive dialogue . 
Attitudes of university youth towards the issue of delinquent juvenile children through new media methods: ( a field study on Minia university students(

*Finding leaders from technicalities and specialists in the field of managing electronic sites particularly youth leaders in purpose of searching sites that encourage on the stray thinking and attempt to present these issues on public opinion and the most important sites that are followed by the youth and find solutions for these issues .

\section{References}

\section{Firstly : Arabic references :}

Magdy Mohammed Abdel Gwad Dgher (2016) : the role of new media methods in forming knowledge and attitudes of university youth towards the phenomenon of terrorism on the internet, a field study, a published thesis about annals of literature and social sciences, Kuwait university . Council of the scientific publication, no. 36 , 453 , June 2016, pp 9- 298 . ( 1763976).

Ekram Ahmed Fouad Alahway (2015) :" problems of new media and methods of coping it on a sample of adolescents ", unpublished doctoral thesis , ( Ain Shams university, institute of post graduates studies for childhood, information department and child culture .

Hassan Abdel Rahman Taher (2015 ) : "youth and media " , a research presented for 12international conference of 
Attitudes of university youth towards the issue of delinquent juvenile children through new media methods: ( a field study on Minia university students(

Islamic seminar for Islamic youth : youth in a changing world " Marrakesh, January 2015.

Samer Sabry Sadek (2014) : "sharing information through social networks during crises and it's reflections on Egyptian youth perception for the crisis " , unpublished master thesis, ( Ain Shams university : faculty of Arts , department of communication and media sciences ).

Haythem Mohammed Youssef (2017) : " university youth attitudes towards Saudi national media methods treatment for issues of family violence", published research on the Arabic journal of media and communication sciences ( Canadian Alahram university, no. 17 , June 2017, pp .1$24)$.

Khalid Hassan Ahmed Luqman (2015) : " the role of new media in forming social attitudes for Sudan youth " , unpublished doctoral thesis , ( Omdurman university - Al Sudan ) .

Hatem Mohammed Atef Abdel Khalik Saad (2004) :"the relationship between adolescents use ( 14-17 years )for the internet and forming their cultural identity -a field study, unpublished master thesis , ( Cairo :Ain Shams 
Attitudes of university youth towards the issue of delinquent juvenile children through new media methods: ( a field study on Minia university students(

university, institute of post graduate studies for childhood).

Fatma Ahmed Ali Nassef (2010) : "designing a guidance program to reduce the degree of violence of delinquent juveniles ", unpublished doctoral thesis ( Ain Shams university, institute of post graduate studies for childhood, department of psychological and social studies) .

Farag Khiary Abdel Gayed Darwish (2010) : "the relationship between publishing crimes news and adolescents attitudes towards different crimes ", unpublished doctoral thesis ( Ain Shams university : institute of post graduate studies for childhood, department of media and child culture) .

Alam on www.abnaaetbefeira.com .

Naglaa Fathy Abdel Kader El Syed (2010) : " the absence of father and juvenile delinquency ", unpublished doctoral thesis , ( Ain Shams university : institute of post graduate studies for childhood, department of psychological studies for children, p.23). 
Attitudes of university youth towards the issue of delinquent juvenile children through new media methods: ( a field study on Minia university students(

\section{Secondly :foreign references :}

Lewis, Marieke :)2102( Op. Cit., p. 36.

Nitika An et al. (2012): Op. Cit., p. 36.

Marina Vastly (2012): Op. Cit., p. 77.

Tasi, C.C. \& Lin (2004): "Taiwanese adolescents' perception and attitudes regarding the internet: exploring gender differences". Adolescence, Vol. 39, win 2004.

Zahir, K. (2010): "The Children Street Committint Crimes in Turkey", Electronic Journal of Social Science, Vol. 9, Issue 32. 